\title{
Surgical complications of Meckel's diverticulae: a review of seven cases
}

\author{
Ewan Alufohai, James Kpolugo and John Onuminya
}

\begin{abstract}
Seven cases of Meckel's diverticulae were reported out of 830 laparotomies performed at Irrua Specialist Teaching Hospital (ISTH), Irrua, Nigeria, between January 1997 and December 2003, giving an incidence of $0.84 \%$ in our series. There were five males and two females. Their mean age was 33 years. Out of the seven cases of Meckel's diverticulae, six presented as surgical emergencies. There were three cases of diverticulitis, two of intestinal obstruction due to bands, and one case formed the apex of an intussusception, which presented as an appendix mass. There were no cases of gastro-intestinal bleeding, fistulae, perforation or tumour. Four of the cases were diagnosed pre-operatively as acute appendicitis or appendix mass and had the typical appendicectomy in addition to the excision of the diverticulum. All excised specimens were confirmed histologically. There was no mortality.
\end{abstract}

\section{INTRODUCTION}

Meckel's diveticulum was first described by Fabricius Hildamus in 1598, while Johann Meckel established its embryonic origin in 1809. ${ }^{1}$ It is a true diverticulum of the terminal ileum and results from incomplete obliteration of the vitelline duct. It is generally accepted to be rare, with a prevalence rate of $0.2-4 \%$, depending on the series whether from surgery or autopsy. ${ }^{1,2}$ It is found within $40 \mathrm{~cm}$ and $90 \mathrm{~cm}$ of the terminal ileum from the ileo-cae-

KEY WORDS: Diverticulum, diverticulits, laparotomy, Ekpoma

Department of Surgery, Faculty of Clinical Sciences, College of Medicine, Ambrose Alli University, P.M.B. 14, Ekpoma, Edo State, Nigeria.

Correspondence: Dr Ewan Alufohai, Department of Surgery, Faculty of Clinical Sciences, College of Medicine, Ambrose Alli University, P.M.B. 14, Ekpoma, Edo State, Nigeria. cal valve. It often contains heterotopic mucosa, commonly gastric mucosa. ${ }^{1-3}$ It is also a cause of pathology in the surgical abdomen where it could be inflamed (diverticulitis), cause intestinal obstruction from bands and intussusception, cause severe gastro-intestinal bleeding, or a persistent umbilical fistula, rarely be part of the content of a littre hernia, or be the seat of a tumour. ${ }^{3-5}$

Where Meckel's diverticulum is responsible for the pathology of the surgical abdomen, it is generally accepted as a diagnostic enigma ${ }^{3,6}$ even in centres with advanced investigative facilities such as magnetic resonance imaging, computerised tomography, endoscopic ultrasonography and Tc-99m pertechnetate imaging. ${ }^{7,8}$ It is for this reason that surgical complications of Meckel's diverticulum seen in our hospital is being highlighted so as to increase the index of suspicion preoperatively in the surgical abdomen.

(C) CMS UNIBEN JMBR 2005; 4(1): 88-91 


\section{METHODS}

The case notes of patients who had laparotomy (including appendicectomies) excluding gynaecological operations done between January 1997 and December 2003 were retrieved manually from the records department. The notes of those who had pathologies referable to Meckel's diverticulum were further analysed in terms of age, sex, preoperative diagnosis, operative diagnosis and type of surgery, as well as the histology of the specimen and outcome of surgery.

\section{RESULTS}

Eight hundred and thirty cases of laparotomy (including appendicectomy) excluding gynaecological operations were done in the seven-year period. Meckel's diverticulum was found in seven cases, giving an incidence of $0.84 \%$. There were five males and two females. The mean age of the patients was 33.0 years with a range of $15-49$ years. In three cases, the diverticulum was inflamed (diverticulitis). In two cases, the presentation was that of intestinal obstruction due to bands, and one case that had been diagnosed as appendix mass turned out to be an intussusception with the apex of the intussuscipiens formed by Meckel's diverticulum. Two of the patients presented with intestinal obstruction due to bands, while one presented as an appendix mass but turned out to be an intussusception with the apex of the intussuscipiens formed by a Meckel's diverticulum.

The seventh case of Meckel's diverticulum was an incidental finding in a 15-year-old, who had gastric outlet obstruction from chronic duodenal ulcer. All three cases of diverticulitis had cuneiform excision of the diverticulum, and appendicectomy was also carried out. The two cases of intestinal obstruction due to bands had excision of the bands and the diverticulum. In the case of intussusception, reduction was done, Meckel's diverticulum was excised and appendicectomy performed. All patients did very well postoperatively.

(C) CMS UNIBEN JMBR 2005; 4(1): 88-91
Histopathological examination revealed four cases of inflammation (three cases of diverticulitis and one case of intussusception), while the two cases of bands were normal diverticulae. There was no report of any heterotopic gastric mucosa particularly in the case that had ulcer surgery. No other pathology commonly identified with Meckel's diverticulum was recorded. The cases are illustrated in Table 1.

\section{DISCUSSION}

The complications of Meckel's diverticulum often present as acute surgical abdomen, and because it is rarely considered in the preoperative diagnosis of this condition, it is frequently missed and the result may often be fatal even with advanced investigative facilities. ${ }^{2,5,7,9}$ This finding was also confirmed in our series where no pre-operative diagnosis implicating Meckel's diverticulum was made, although no case of fatality was reported.

The mean age of 33.0 years in our series is in agreement with the reports of other workers that most complications of Meckel's diverticulum occur before the age of 40 years. $^{2}$ This is supportive of the view that asymptomatic cases of Meckel's diverticulum seen in the paediatric age group should be excised. ${ }^{5}$ This was done in our series for the incidental finding in a 15-year-old boy.

Of the six cases of complicated Meckel's diverticulum in our series, four cases were due to inflammation that was misdiagnosed as appendicitis or appendix mass. This finding further stresses the need to search for Meckel's diverticulum in cases diagnosed as acute appendicitis but with grossly normal-looking appendix..$^{10,11}$

The histology reports of our specimen in this series did not reveal any heterotopic gastric mucosa even in the incidental finding, which was a case of complicated duodenal ulcer (Figure 1). Other known complications of Meckel's diverticulum such as peritonitis from perforated diverticulitis, umbilical fistula or tumours were not recorded. ${ }^{1,2,4,6,7}$ 


\section{Table 1 Case illustration for Meckel's diverticulum}

\begin{tabular}{|c|c|c|c|c|c|c|c|}
\hline S/No. & $\begin{array}{l}\text { Age } \\
\text { (years) }\end{array}$ & Sex & $\begin{array}{l}\text { Pre-operative } \\
\text { diagnosis }\end{array}$ & $\begin{array}{l}\text { Operative } \\
\text { diagnosis/ } \\
\text { findings }\end{array}$ & Type of surgery & $\begin{array}{l}\text { Histology } \\
\text { report }\end{array}$ & $\begin{array}{l}\text { Postoperative } \\
\text { remarks }\end{array}$ \\
\hline 1. & 15 & $\mathrm{M}$ & $\begin{array}{l}\text { Gastric outlet } \\
\text { obstruction } \\
\text { secondary to } \\
\text { DU }\end{array}$ & $\begin{array}{l}\text { Pyloric stenosis } \\
\text { from DU. } \\
\text { Meckel's } \\
\text { diverticulum } \\
\text { Meckel’s } \\
\text { diverticulum }\end{array}$ & $\begin{array}{l}\text { Truncal } \\
\text { vagotomy }+ \\
\text { pyloroplasty. } \\
\text { Excision of }\end{array}$ & $\begin{array}{l}\text { Normal ileal } \\
\text { mucosa }\end{array}$ & Uneventful \\
\hline 2. & 25 & $\mathrm{~F}$ & $\begin{array}{l}\text { Appendix } \\
\text { mass }\end{array}$ & $\begin{array}{l}\text { Ileo-caecal } \\
\text { intussusception } \\
\text { with oedematous } \\
\text { diverticulum }\end{array}$ & $\begin{array}{l}\text { Reduction, } \\
\text { excision and } \\
\text { appendicectomy } \\
\text { through } \\
\text { extended grid } \\
\text { iron incision }\end{array}$ & $\begin{array}{l}\text { Chronically } \\
\text { inflamed } \\
\text { mucosa of a } \\
\text { Meckel's } \\
\text { diverticulum }\end{array}$ & Uneventful \\
\hline 3. & 29 & M & $\begin{array}{l}\text { Acute } \\
\text { appendicitis }\end{array}$ & $\begin{array}{l}\text { Oedematous } \\
\text { and hyperaemic } \\
\text { mucosa of } \\
\text { Meckel's } \\
\text { diverticulum }\end{array}$ & $\begin{array}{l}\text { Lanz incision } \\
\text { Excision of } \\
\text { diverticulum } \\
\text { Appendicectomy }\end{array}$ & $\begin{array}{l}\text { Chronically } \\
\text { inflamed } \\
\text { mucosa of a } \\
\text { Meckel's } \\
\text { diverticulum }\end{array}$ & Uneventful \\
\hline 4. & 36 & $\mathrm{~F}$ & $\begin{array}{l}\text { Recurrent } \\
\text { appendicitis }\end{array}$ & $\begin{array}{l}\text { Hyperaemic } \\
\text { oedematous } \\
\text { Meckel's } \\
\text { diverticulum }\end{array}$ & $\begin{array}{l}\text { Lanz incision } \\
\text { Excision of } \\
\text { diverticulum } \\
\text { Appendicectomy }\end{array}$ & $\begin{array}{l}\text { Chronically } \\
\text { inflamed } \\
\text { mucosa of } \\
\text { Meckel's } \\
\text { diverticulum }\end{array}$ & Uneventful \\
\hline 5. & 38 & $\mathrm{M}$ & $\begin{array}{l}\text { Intestinal } \\
\text { obstruction } \\
\text { band }\end{array}$ & $\begin{array}{l}\text { Meckel's } \\
\text { diverticulum } \\
\text { of band and } \\
\text { diverticulum }\end{array}$ & $\begin{array}{l}\text { Mid paramedian } \\
\text { incision, excision }\end{array}$ & $\begin{array}{l}\text { Normal ileal } \\
\text { mucosa }\end{array}$ & Uneventful \\
\hline 6. & 42 & M & $\begin{array}{l}\text { Recurrent } \\
\text { appendicitis }\end{array}$ & $\begin{array}{l}\text { Hyperaemic and } \\
\text { oedematous } \\
\text { mucosa of } \\
\text { Meckel's } \\
\text { diverticulum }\end{array}$ & $\begin{array}{l}\text { Grid iron } \\
\text { incision, excision } \\
\text { of diverticulum + } \\
\text { appendicectomy }\end{array}$ & $\begin{array}{l}\text { Chronically } \\
\text { inflamed } \\
\text { diverticulum }\end{array}$ & Uneventful \\
\hline 7. & 49 & $\mathrm{M}$ & $\begin{array}{l}\text { Intestinal } \\
\text { obstruction }\end{array}$ & $\begin{array}{l}\text { Meckel's } \\
\text { diverticulum } \\
\text { band }\end{array}$ & $\begin{array}{l}\text { Mid-paramedian } \\
\text { incision, excision } \\
\text { of diverticulum + } \\
\text { band }\end{array}$ & $\begin{array}{l}\text { Normal ileal } \\
\text { mucosa }\end{array}$ & Uneventful \\
\hline
\end{tabular}

All cases that had classical appendicectomy incisions through which the diverticulum was excised had appendicectomy in addition, so as not to create any diagnostic problem in future if features of appendicitis are encountered in the same patient.
No case of mortality was recorded, which may be due to prompt surgical intervention.

Being a retrospective study, the one case of incidental finding at surgery may not be representative enough, a prospective study is necessary to give a more reliable prevalence rate in our environment. 


\section{References}

1. Griffen WO Jnr. Meckel's diverticulum In: DC Sabiston (Ed.). Textbook of Surgery. Philadelphia: WB Saunders Corporation, 1986; 946.

2. Mackey WC and Dineen P. A fifty-year experience with Meckel's diverticulum. Surg Gynaecol Obstet 1983; 156(1): 56-64.

3. Park SM, Chun HJ, Jeen YT, et al. A case of chronic gastrointestinal bleeding from a Meckel's diverticulum detected by wireless capsule endoscopy. Korean J Gastroenterol 2004; 43(2): 125-128.

4. Szentpali K, Palotas A, Wolfard A, et al. A gastrointestinal stromal tumour presenting in a perforated Meckel?s diverticulum. Can J Surg 2004; 47(1): 70.

5. Carpenter SS and Grillis ME. Meckel's diverticulitis Secondary to carcinoid tumour: an unusual presentation of the acute abdomen in an adult. Curr Surg 2003; 60(3): 301-
303.

6. Bennett GL, Birnbaun BA and Balthazar EJ. CT of Meckel's diverticulitis in 11 patients. Am J Roentgenol 2004; 182(3): 625-629.

7. Danzer D, Gervaz P, Platon A and Poletti PA. Bleeding Meckel's diverticulum diagnosis: an unusual indication for computed tomograph. Abdom Imaging 2003; 28(5): 631-633.

8. Datz FL and Taylor A Jr. Utility of bladder lavage in Meckel's scanning. Clin Nuec Med 1985; 10(11): 804-806.

9. Vork JC and Kristensen IB. Mackel's diverticulum and intestinal obstruction report of a fatal case. Forensic Sci Int 2003; 138(1-3): 114-115.

10. Odusanya OO and Alufohai E. Differential diagnosis of appendicitis seen in a rural practice in Nigeria. Nig Med Pract 2002; 41(3/ 4): 31-33.

11. Alufohai E. Coping with Rural Surgery. Ibadan: Sam Bookman, 2000; 57-62. 